\title{
Pendampingan dalam Perencanaan Penanaman Bawang Merah pada Kelompok Tani Harapan Jaya Kelurahan Talang Keramat Kecamatan Talang Kelapa Kabupaten Banyuasin
}

\author{
Jovan Febriantoko \\ Program Studi Akuntansi, Politeknik \\ Palcomtech, Palembang, Indonesia \\ E-mail: jovanfebriantoko@gmail.com
}

\author{
Riana Mayasari \\ Jurusan Akuntansi, \\ Politeknik Negeri Sriwijaya, Palembang, \\ Indonesia
}

\section{Bastani Sepindjung \\ Fakultas Pertanian, Universitas Tridinanti, Palembang, Indonesia}

\section{Article History:}

Received: 2019-10-16

Revised: 2020-01-17

Accepted: 2020-05-31
Keywords: Shallot, Product

Design, agriculture, agribusiness

\begin{abstract}
Harapan Jaya Farmers Group runs agricultural activities, located in Talang Kramat Village, Talang Kelapa Regency, which was then called the partner. Based on the preliminary research, several significant problems were found regarding the land condition, equipment, partners' understanding, packaging, and promotion. This community partnership program was based on community development approach, intended to solve problems by conducting preimplementation socialization and discussion, seeding shallots, planting media preparation, liming and fertilizing, planting shallots, designing agricultural equipment and conducting product marketing training. The results indicated that partners: (1) have completely understood about the process of planting shallots both from seed and from shallots tuber seedlings; (2) followed the working mechanism of agricultural aids thus they can repair the damage of their simple tools, and (3) became independent both personally and in groups. Besides, young partners could manage the web for marketing process, all of which can increase the potential of the agriculture field.
\end{abstract}

\section{Pendahuluan}

Pertanian merupakan suatu proses pemanfaatan sumber daya hayati dengan melibatkan manusia demi mencukupi bahan pangan, sumber energi, bahan baku dan merupakan proses pengelolaan lingkungan hidup sekitar. Pertanian menjadi bagian penting bagi masyarakat, sehingga perlu diberdayakan secara maksimal'1.

1 Fadhli Almu'iini Ahda, “Aplikasi Penentuan Jenis Penyakit Yang Memungkinkan Bisa Diterapi Dengan Bawang Merah Dengan Menggunakan Metode Naïve Bayes," Jurnal Ilmiah Teknologi Informasi Asia 9, no. 1 (2015): 34-44. 
Salah satu kelompok masyarakat yang menjalankan kegiatan pertanian adalah Kelompok Tani Harapan Jaya yang berlokasi di Jalan Kauman RT 15, RW 03 Kelurahan Talang Kramat, Kecamatan Talang Kelapa, Banyuasin, Sumatera Selatan. Kelompok Tani Harapan Jaya di Ketuai oleh Bapak Karyono dengan jumlah anggota aktif sebanyak 12 orang ini menjadi mitra dalam pelaksanaan Pengabdian kepada Masyarakat.

Proses bercocok tanam yang dilakukan kelompok Tani Harapan Jaya secara umum masih dilakukan secara manual, dimulai dari pembibitan, penyiraman dan perawatan namun dalam proses pembajakan menggunakan bantuan alat bajak pultifator. Proses pengemasan hasil pertanian juga dilakukan secara manual, yakni mengikat sayuran menggunakan karet dan tali plastik lalu dibungkus plastik, menjual hasil panen ke pedagang di pasar tradisional dan pembeli mendatangi perkebunan secara langsung.

Tidak jarang Kelompok Tani Harapan Jaya menghadapi permasalahan cuaca yang tidak menentu, keterbatasan alat pertanian dan pengetahuan SDM tentang teknik bercocok tanam yang belum memadai, pengelolaan keuangan belum tepat, dan belum adanya promosi yang efisien dan efektif, sehingga hasil yang didapatkan masih belum maksimal.

Berdasarkan hasil observasi awal sebagaimana diuraikan di atas, maka diketahui beberapa permasalahan utama mitra dampingan sebagai berikut: (1) Masalah cuaca masih sangat berpengaruh terhadap hasil pertanian mitra; (2) Alat pertanian yang dimiliki mitra yang terbatas yang menyebabkan terhambat nya proses produksi pertanian; (3) Mitra belum mampu memahami teknik pembudidayaan bawang merah yang tepat dalam kondisi cuaca seperti di Kota Palembang ini, padahal bawang merah merupakan salah satu komoditas pertanian yang cukup menjanjikan dan banyak dibutuhkan namun belum banyak petani yang mampu menyediakan kebutuhan bawang merah tersebut2; (4) Hasil pertanian hanya dikemas dengan bungkus kantong plastik dan kardus sehingga secara penampilan belum bisa bersaing dan menarik bagi konsumen kelas menengah atas. Mereka belum mampu membuat design produk pertanian yang menarik, sehingga hasil pertanian yang dihasilkan mitra kalah bersaing dengan petani yang lebih modern; (5) Kurangnya promosi juga merupakan kendala mitra yang sangat nyata, mitra hanya memasarkan produknya pada pihak yang mereka kenal saja. Hal tersebut dikarenakan mitra belum mengetahui bagaimana cara memasarkan produk pertaniannya melalui jejaring sosial atau melalui media online, padahal pemasaran melalui media online seperti halnya website itu sangat membantu di era saat ini.

Berdasarkan permasalahan utama mitra tersebut, maka Tim PKM akan melakukan pendampingan dalam perencanaan penanaman bawang merah pada mitra

2 Haris Fatori Aldila, Anna Fariyanti, and Netti Tinaprilla, "Daya Saing Bawang Merah Di Wilayah Sentra Produksi Di Indonesia," Jurnal Manajemen \& Agribisnis 14, no. 1 (2017): 43. 
dampingan.

\section{Metode}

Berdasarkan permasalahan utama mitra maka, maka pendekatan yang digunakan dalam pengabdian masyarakat menggunakan pendekatan community development dengan melaksanakan beberapa tahapan sebagaiman tersaji dalam bagan berikut:

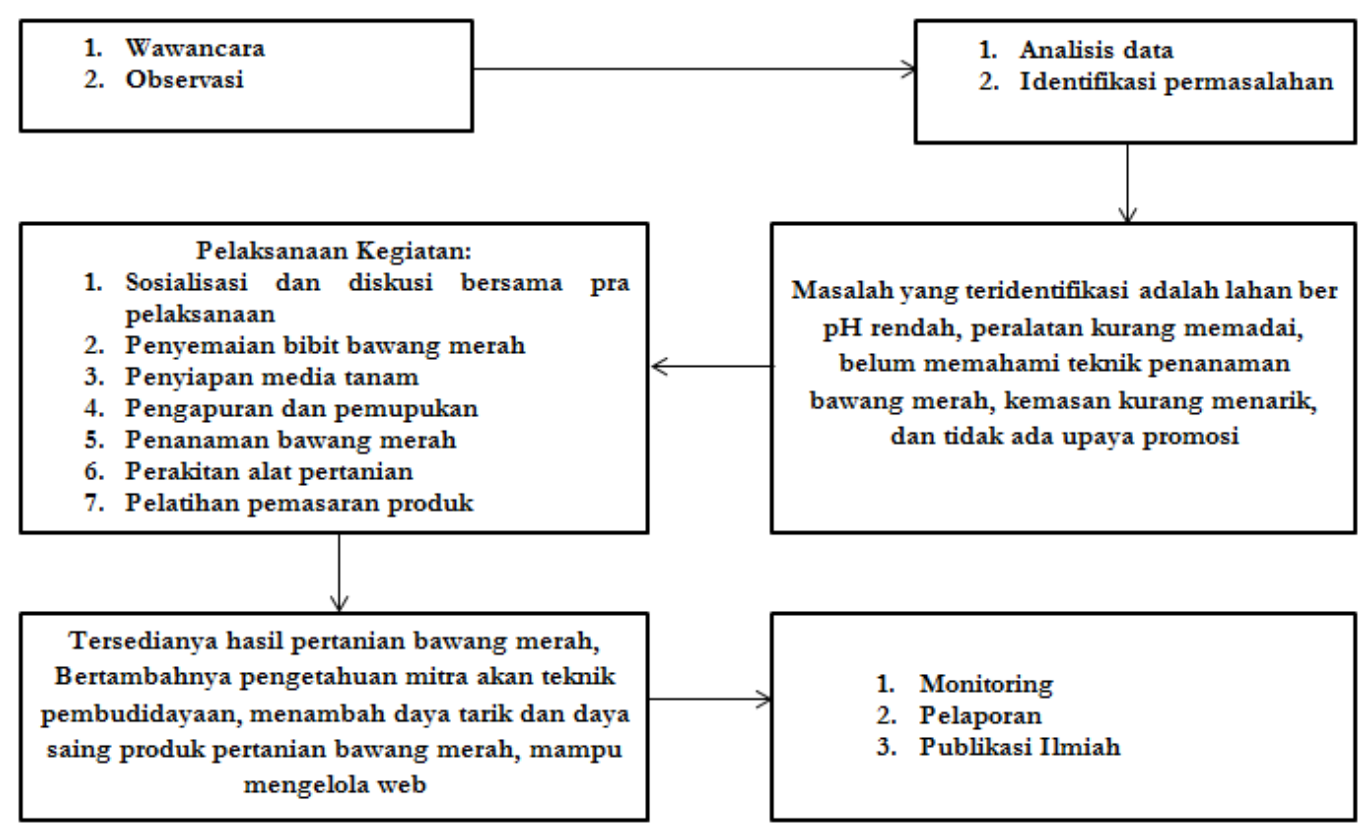

Gambar 1. Tahapan Pelaksanaan Kegiatan Pengabdian Masyarakat

\section{Tahap Identifikasi Permasalah dan Perencanaan}

Tahap ini dilakukan dengan wawancara terhadap mitra melalui teknik wawancara mendalam. Wawancara mendalam adalah teknik pengumpulan data untuk suatu penelitian untuk menemukan permasalahan dan mengetahui hal-hal mendalam yang bersumber pada informan langsung ${ }^{3}$. Wawancara mendalam digunakan untuk mengetahui permasalahan secara terperinci dan mendalam. Wawancara dilakukan berdasarkan 2 bidang utama yang akan di angkat yaitu bidang manajemen usaha dan bidang pertanian.

Wawancara dilakukan terhadap ketua dan anggota kelompok tani di waktu dan tempat yang berbeda. Kegiatan ini dilakukan oleh semua anggota tim yang terdiri dari Ir. Bastani Sepindjung, MP, Riana Mayasari, SE., Ak., M.Acc., CA dan Jovan Febriantoko, SE., Ak., M.Acc., CA. dan di bantu tim eksternal. Proses perencanaan ini membutuhkan

3 L. Gelling, “Qualitative Research,” Qual. Res., 2015.. 
peran aktif mitra dalam menyampaikan kebutuhan dan permasalahan yang dihadapi.

Selain dilakukan wawancara untuk menggali permasalahan mitra, dalam tahap ini juga dilakukan perencanaan program kegiatan yang dihasilkan dari rumusan permasalahan yang diolah bersama-sama dengan mitra. Secara teknis, Tim melakukan FGD dengan seluruh anggota mitra dan merumuskan agenda kegiatan pendampingan, mulai dari latar belakang permasalahan, tujuan kegiatan, target yang akan dicapai sehingga pendampingan yang dilakukan Tim akan dapat membantu mengurai permasalahan mitra dampingan. Kegiatan ini dilaksanakan Riana Mayasari, S.E., M.Acc., Ak., CA. dan Jovan Febriantoko, SE., M.Acc., AK., CA.

\section{Tahapan Pelaksanaan Program}

Dalam tahap pelaksanaan kegiatan pendampingan ini terdiri dari beberapa aktivitas program, diantaranya: (1) Sosialisasi dan diskusi bersama pra pelaksanaan; (2) Penyemaian bibit bawang merah; (3) Penyiapan media tanam; (4) Pengapuran dan pemupukan; (5) Penanaman bawang merah; (6) Perakitan knapsack sprayer; (7) Training pemasaran produk bawang merah; dan (8) Pendampingan dan perawatan tanaman. Tahapan-tahapan akan dilaksanakan untuk melakukan pendampingan perencanaan penanaman bawang merah yang baik bagi mitra dampingan.

Lebih lanjut, tahapan pelaksanaan program ini lebih memfokuskan untuk melakukan pendampingan perencanaan dalam bidang manajemen pertanian, bidang permasalahan produksi, bidang desain produk, bidang tata kelola keuangan, bidang pemasaran produk bawang merah.

1. Bidang Manajemen. Pendampingan dalam bidang manajemen ini dilakukan dengan melakukan FGD dengan seluruh anggota mitra dampingan tentang latar belakang, target capaian, sasaran dan tujuan dalam pendampingan manajemen penanaman bawang merah. Kegiatan ini dilaksanakan oleh Riana Mayasari, S.E., M.Acc., Ak., CA. dan Jovan Febriantoko, SE., M.Acc., AK., CA.

2. Bidang Permasalahan Produksi. Implementasi kegiatan ini dilakukan dengan pendampingan terkait penggunaan teknologi yang bisa digunakan oleh para petani untuk meningkatkan hasil produksi pertanian bawang merah sehingga tidak hanya mengandalkan tenaga kerja manusia ${ }^{4}$. Teknologi yang diberikan adalah Knapsack Sprayer yang akan dirakit sendiri oleh mitra. Perakitan Knapsack Sprayer akan di pandu oleh Ir. Bastani Sepindjung, MP., Riana Mayasari, S.E., M.Acc., Ak., CA., Jovan Febriantoko, S.E., M.Acc., Ak., dan Tim Pembantu Pelaksana

3. Bidang Desain Produk. Desain isolasi berlogo di rencanakan untuk memperbaiki

4 Anna Fatchiya and Siti Amanah, "Penerapan Inovasi Teknologi Pertanian Dan Hubungannya Dengan Ketahanan Pangan Rumah Tangga Petani," Jurnal Penyuluhan 12, no. 2 (2016): 190-197. 
daya tarik akan kemasan juga akan diberikan ${ }^{5}$. Logo atas sayuran yang dipanen juga akan di design dengan menggunakan alat bantu komputer sehingga akan dihasilkan logo kemasan yang menarik dan berdaya saing ${ }^{6}$. Dalam kegiatan ini akan didampingi oleh pakar yaitu Andika Widyanto, S.Kom., M.Kom, Ir. Bastani Sepindjung, MP. dan Jovan Febriantoko, S.E., M.Acc., Ak.

4. Bidang Permasalahan Manajemen dan Keuangan. Pelatihan dan bantuan terkait sistem pengelolaan manajemen dan keuangan dasar juga akan dilakukan, yang diharapkan hal tersebut memungkinkan para petani dalam menentukan berapa pengeluaran dan pendapatan mereka secara berkala. Berdasakan pengetahuan tersebut diyakini bahwa para petani bisa mengetahui keuntungan ataupun kerugian mereka. Dalam kegiatan ini akan dilaksanakan dibawah panduan Riana Mayasari, SE.,M.Acc.,Ak.,CA., dan Jovan Febriantoko, S.E., M.Acc., Ak. selaku pakar pengelolaan keuangan sekaligus di bantu oleh tim pembantu pelaksana

5. Bidang Permasalahan Pemasaran. Dalam hal pelatihan dan bantuan sistem pemasaran yang lebih baik dan tidak hanya berfokus pada menunggu pihak yang membutuhkan hasil pertanian dan menjual pertanian sebatas kepada pihak yang dikenal, maka dalam kegiatan ini tim mendampingi mitra dalam pemasaran hasil panen melalui website. Kegiatan ini akan dilaksanakan dibawah praktisi dibidang ilmu teknologi dan informasi komputer yaitu Andika Widyanto, S.Kom., M.Kom. dan Jovan Febriantoko, S.E., M.Acc., Ak. Dan Ir. Bastani Sepindjung, MP.

Secara umum, tahapan implementasi program ini dilakukan oleh seluruh anggota tim, konsultan teknologi, dan tim pembantu pelaksanaan. Peran mitra dalam tahapan ini sebagai pelaksana lapangan.

\section{Tahapan Evaluasi dan Pelaporan}

Pada tahap kegiatan akhir yaitu tahap evaluasi dengan menilai hasil yang dicapai selama proses pendampingan apakah menunjukan peningkatan capaian atas keseluruhan tujuan kegiatan. Hasil kegiatan yang telah dicapai akan analisis untuk digunakan sebagai bahan evaluasi bersama dan memberikan feedback kepada mitra dampingan. Dengan demikian, maka mitra dampingan akan dapat mengetahui tingkat ketercapaian program serta bagaimana rencana pengembangan yang harus dilakukan oleh kelompok Tani. Selain itu, Tim pelaksana juga akan tetap melakukan proses pemantauan dan tindak lanjut kegiatan sebagai wujud pertanggungjawaban kepada masyarakat.

5 Jovan Febriantoko and Hendra Rotama, "Evaluasi Potensi Penerimaan Pendapatan Asli Daerah Bidang Pariwisata Di Indonesia" (2018).

6 Rani Septiawati et al., "Pemanfaatan Limbah Kain Perca Sebagai Alternatif Peluang Usaha," Comvice: Journal of community service 3, no. 1 (2019): 1-8. 


\section{Partisipasi Mitra Dalam Pelaksanaan Program}

Mitra dalam Kegiatan ini adalah anggota Kelompok Tani Harapan Jaya yang berkedudukan di : Jl. Kauman, RT15/RW03, Kelurahan Talang Keramat, Kecamatan talang adalah sebagai pelaksana lapangan. Seluruh anggota untuk selanjutnya, dibimbing secara penuh untuk menerapkan teknologi dan pelatihan yang dianjurkan. Dari kegiatan ini diharapkan akan terjadi pertukaran pengetahuan sehingga akan berdampak pada peningkatan pendapatan masyarakat tani di daerah sekitarnya. Peran serta aktif mitra sangat berpengaruh terhadap kelangsungan teknologi yang telah dicoba untuk di implementasikan dan di rancang.

\section{Hasil dan Diskusi}

\section{Hasil Tahapan Identifikasi Permasalahan dan Perencanaan}

Kegiatan Pertama yang dilakukan sebelum sosialisai dan diskusi pra pelaksanaan kegiatan adalah dengan melakukan wawancara secara mendalam. Wawancara yang dilakukan menghasilkan informasi yang berguna untuk menentukan topik sosialisasi dan diskusi dalam kelompok agar tidak keluar dari topik permasalahan yang di hadapi. Selain melakukan wawancara penulis juga melakukan observasi lapangan untuk mendukung hasil wawancara7 ${ }^{7}$. Berdasarkan Kegiatan diatas dapat ditarik subuah permasalahan yang 98\% sesuai dengan yang di alami oleh kelompok tani. Permasalahan utama yang diperoleh adalah belum berpengalaman menanam bawang, ketidakmampuan revitalisasi lahan, dan masih gagap teknologi.
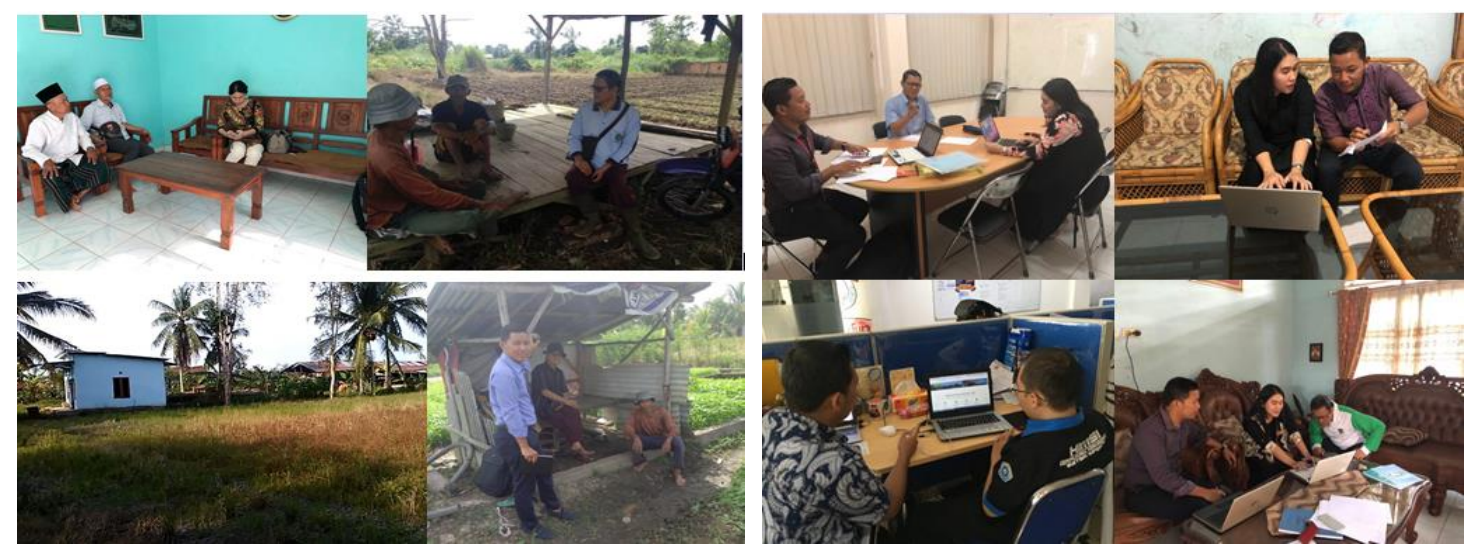

Gambar 2. Wawancara dengan mitra dan observasi (kiri) dan proses Perencanaan kegiatan dengan tim (kanan)

\section{Tahapan Pelaksanaan Program}

Dalam tahapan pelaksanaan program ini diawali FGD dengan mitra dampingan

7 Wendy Olsen, “Observation Methods,” Data Collect. Key Debates Methods Soc. Res (2012). 
dalam bentuk pemaparan hasil temuan awal dari mapping permasalahan yang dihadapi oleh mitra dampingan melalui wawancara mendalam dan observasi lapangan ${ }^{8}$. Permasalahan yang dipaparkan dalam sosialisasi telah sesuai dengan kondisi yang dialami oleh kelompok tani.

Berdasarkan permasalahan yang telah dipaparkan dalam FGD tersebut, maka tahapan berikutnya akan dilakukan kegiatan yang dapat mengurangi permasalahan yang terjadi. Kegiatan yang telah di sepakati bersama yaitu sebagaimana berikut:

1. Sosialisasi dan diskusi bersama pra pelaksanaan

Kegiatan sosialisai dan diskusi pra pelaksanaan dilakukan bersama antara mitra dengan tim pelaksana. Kegiatan ini berisikan arahan kegiatan yang akan dilaksanakan dan diskusi dengan petani.

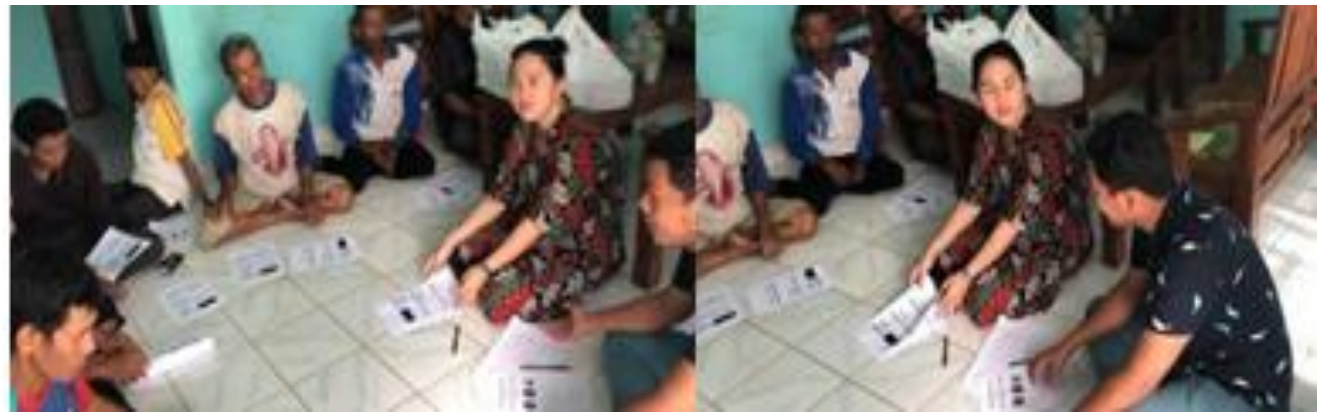

Gambar 3. Sosialisasi dan diskusi dengan mitra

2. Penyemaian bibit bawang merah

Proses penyemaian dilakukan oleh mitra dengan menggunakan benih Sanren-F1 yang merupakan jenis benih hibrida unggulan. Sebelum disemai tanah dicek kelembabannya, pH dan suhu tanah yang di pandu oleh tim pelaksana. Mitra mempraktikan cara melakukan penyemaian dan mampu memahmi tahapannya dengan baik.

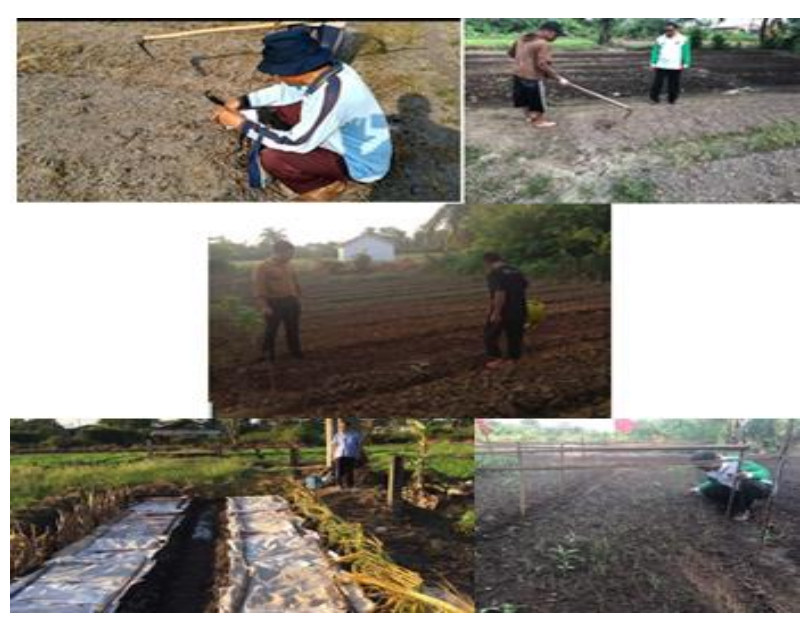

Gambar 4. Penyemaian Benih Bawang Merah

8 Dwi Eko Waluyo, Uci Yuliati, and Joko Triwanto, "IbM Pondok Pesantren Wirausaha Agro Industri," IbM Pondok Pesantren Wirausaha Agro Industri 3, no. 1 (2016): 9-24. 
3. Penyiapan media tanam

Sambil menunggu pertumbuhan hasil penyemaian mitra diajak untuk penyiapan media tanam. Media yang akan ditanami harus dibuat bedengan terlebih dahulu. Setelah itu melakukan pemasangan mulsa jika diperlukan. Pemasangan mulsa dilakukan setelah pengapuran dan pemupukan.

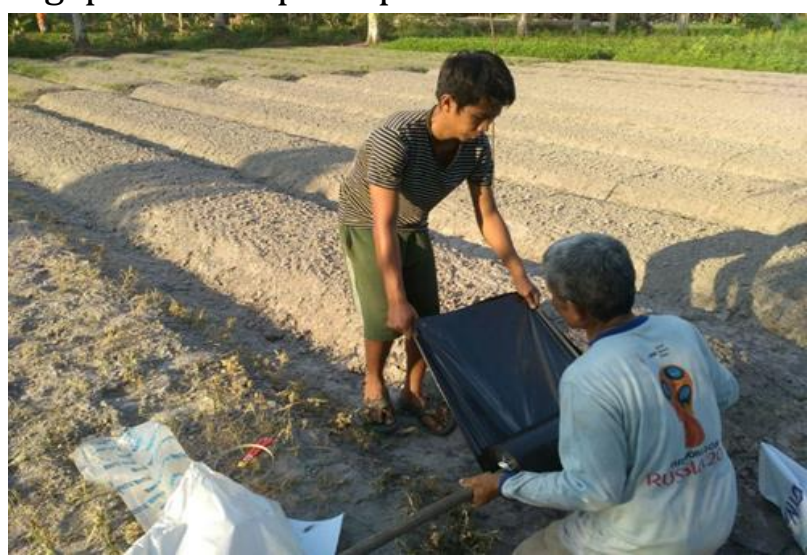

Gambar 5. Penyiapan Media Tanam

4. Pengapuran dan pemupukan

Proses pengapuran digunakan untuk menstabilkan $\mathrm{pH}$ tanah untuk mendapatkan kondisi yang ideal dalam menanam bawang merah. Sedangkan pemupukan digunakan untuk meningkatkan unsur hara tanah. Kegiatan ini dinamakan revitalisasi lahan. Proses ini dilakukan dengan berbagai bahan. Semua bahan di campur dan di implementasikan oleh petani berdasarkan intruksi tim pelaksana. Dengan demikian kemampuan merevitalisasi lahan mitra meningkat. Revitalisasi lahan seperti dapat digunakan untuk lahan selain untuk penanaman bawang merah. Sehingga hasil sayuran yang di panen lebih baik.

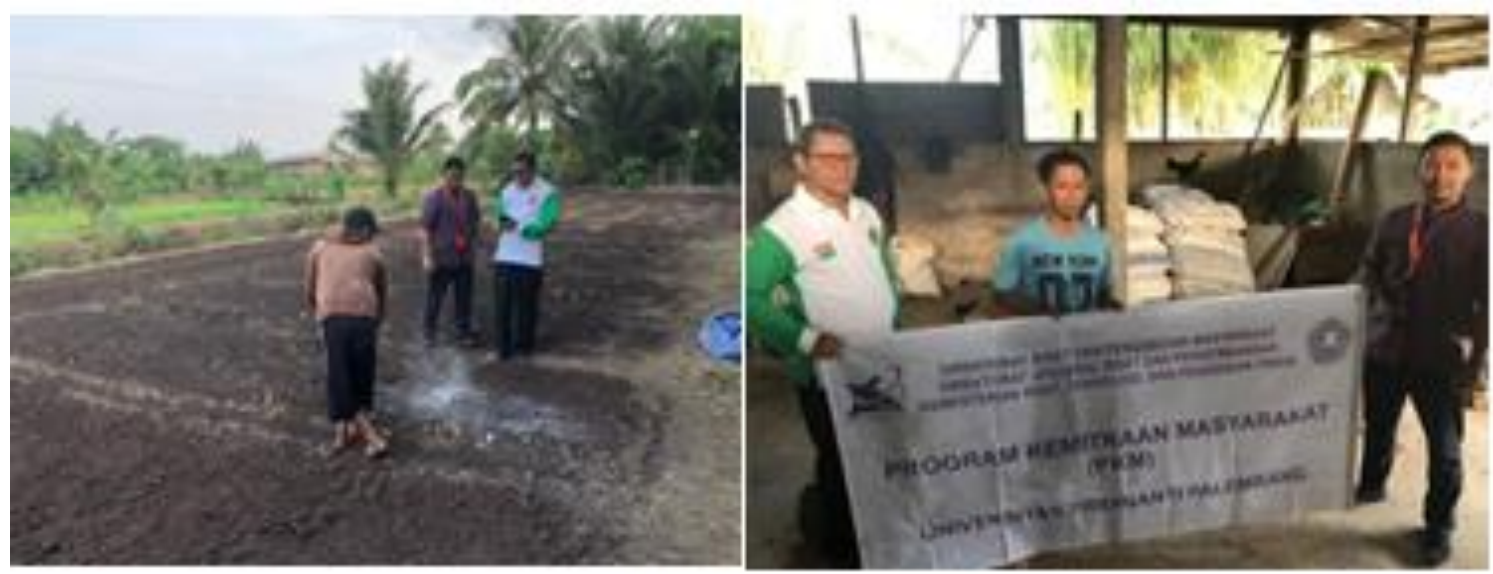

Gambar 6 Revitalisasi Lahan

5. Penanaman bawang merah

Penanaman bawang merah dilakukan dengan benih yang telah disemai lalu dipindahkan dan dengan umbi. Penggunaan benih hibrida memiliki hasil yang lebih baik karena memiliki daun yang lebat dan lebih tahan hama. Mitra mampu memahami proses menanam bawang merah dengan baik. Peningkatan kemampuan 
teknik penanaman bawang merah dapat menghapus pesimis mitra mengenai pertanian bawang merah di lahan ber $\mathrm{pH}$ rendah.

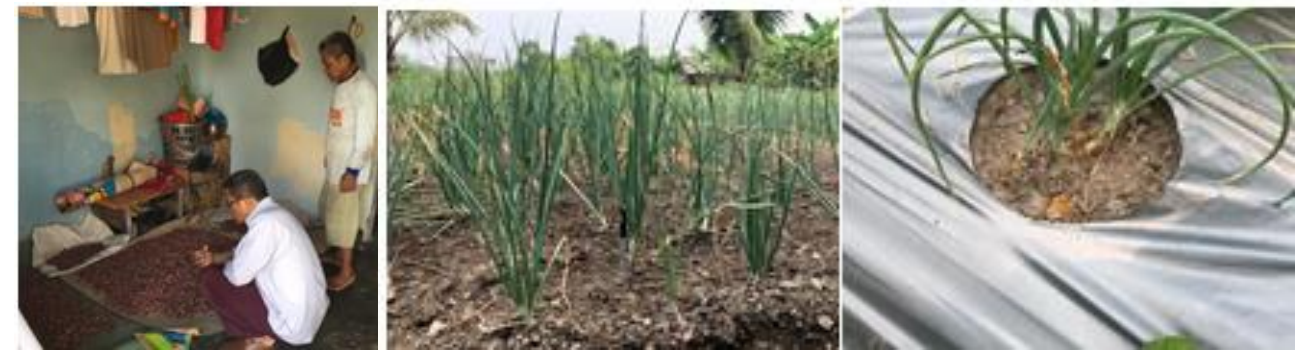

Gambar 7 Penanaman Bawang Merah

6. Perakitan alat bantu pertanian

Kegiatan perakitan alat bantu pertanian diharapakan bermanfaat untuk menambah pengetahuan mitra mengenai mekanisme kerja alat-alat pertanian. Kegiatan ini memberikan dampak kepada mitra terkait kemandirian dalam perbaikan alat pertanian yang mereka miliki dikarenakan mitra telah memahami mekanisme alat pertanian tersebut. Dengan kegiatan ini perspektif masyarakat mengenai kemandirian meningkat.

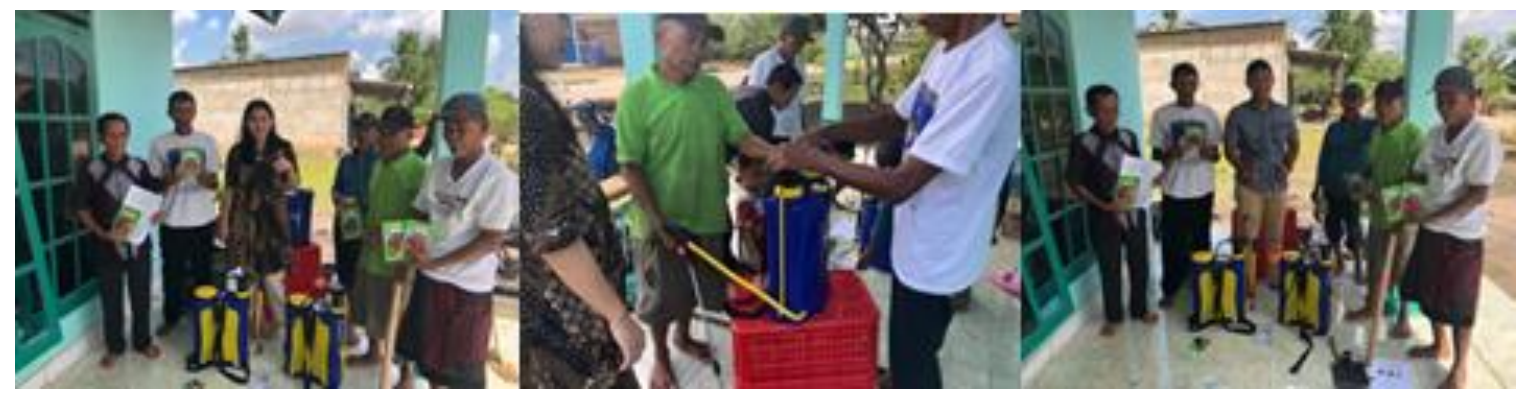

Gambar 8 Perakitan Alat Pertanian

7. Pelatihan pemasaran produk

Pelatihan pemasaran hasil pertanian dilakukan melalui teknologi informasi. Mitra dibuatkan web dengan alamat harapanjaya.org. Proses pengelolaan web dilakukan oleh mitra sendiri dengan cara dilatih terlebih dahulu. Pelatihan pengelolan web sebagai alat bantu promosi hasil pertanian diikuti anggota mitra yang memiliki umur relatif muda. Hal ini dikarenakan semangat anggota mitra yang masih muda lebih baik, terutama untuk mempelajari bidang teknologi informasi. Pengelolaan web cukup sederhana, sehingga mitra cepat memahami dan mampu melakukan pengelolaan web. Web terlihat menarik dikarenakan pengemasan produk pertanian sudah memiliki label sesuai dengan nama mitra. 


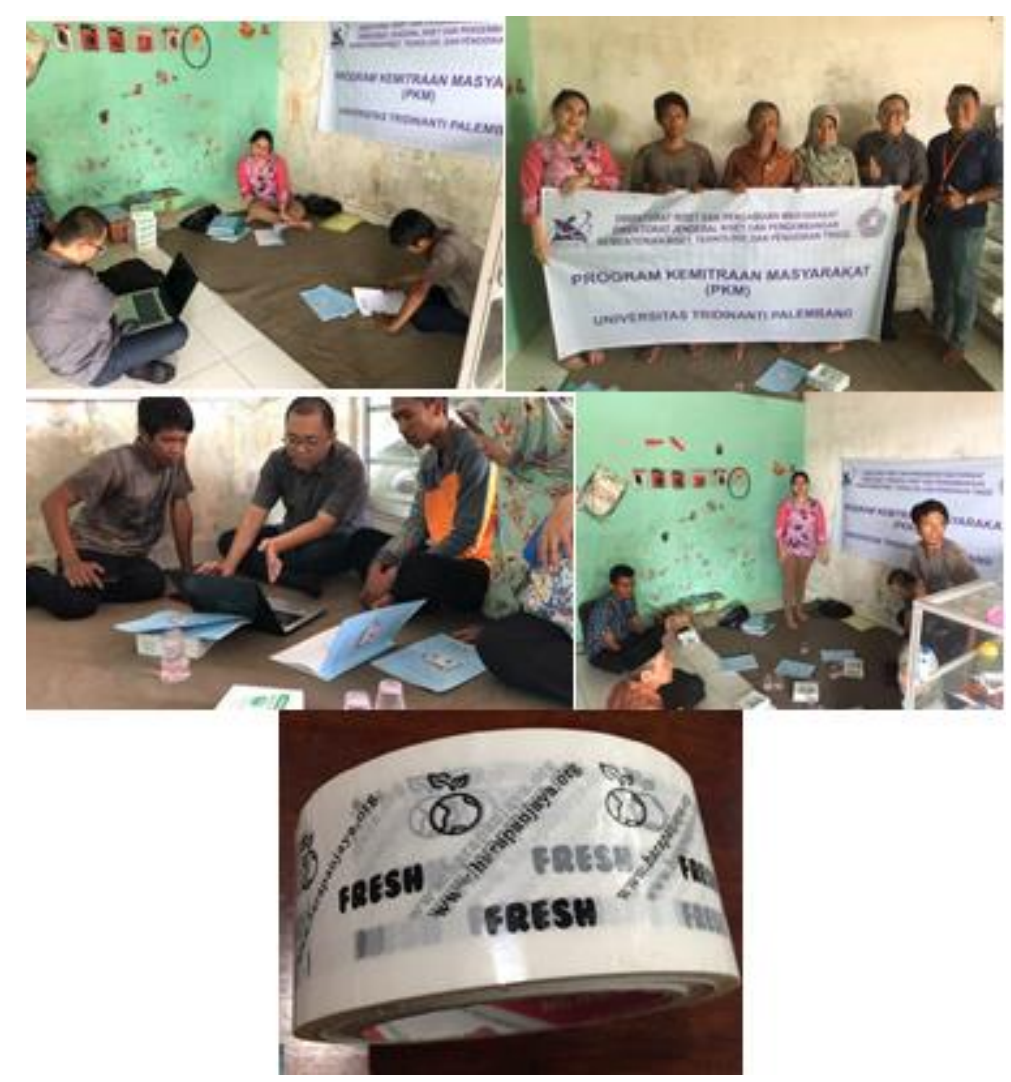

Gambar 9 Pelatihan Pemasaran Produk

\section{Tahap Evaluasi dan Pelaporan Kegiatan}

Tahapan evaluasi dan pelaporan dilakukan melalui proses monitoring mulai dari kegiatan awal proses pendampingan sampai implementasi dalam pendampingan yang dilengkapi dengan pengumpulan dokumen pelaksanaan, serta publikasi ilmiah. Selain sebagai pertanggungjawaban pelaksanaan kegitan kepada DRPM Kementerian Riset, Teknologi dan Pendidikan Tinggi selaku pemberi hibah, kegiatan ini menjadi bahan dasar bagi mitra untuk dilakukan kegiatan pengembangan kualitas Kelompok Tani Harapan Jaya.

\section{Kesimpulan}

Berdasarkan pemaparan seluruh kegiatan yang telah terlaksana dapat ditarik sebuah kesimpulan bahwa mitra dalam kegiatan ini telah mengetahui permasalahan utama yang dihadapi mitra. Melalui kegiatan ini mitra $100 \%$ telah memahami proses penanaman bawang merah baik dari benih maupun dari bibit umbi bawang merah, mitra 100\% mampu memahami mekanisme kerja alat bantu pertanian sehingga mampu memperbaiki sendiri kerusakan alat sederhana dan mitra yang usianya relatif muda $100 \%$ mampu mengelola web sehingga diharapkan akan mempermudah proses pemasaran. Peningkatan kemampuan yang dimiliki mitra maka dapat meningkatkan 
kemandirian mitra baik secara personal maupun kelompok. Bertambahnya kemampuan bidang pertanian terutama mengenai penanaman bawang merah mampu menghapus pandangan pesimis tentang penanaman bawang merah di tanah berawa dan ber $\mathrm{pH}$ rendah.

\section{Ucapan Terimakasih}

Terimakasih disampaikan kepada kepada DRPM Kementerian Riset, Teknologi dan Pendidikan Tinggi, sehingga Program Pengabdian Masyarakat ini dapat terlaksana dengan baik dan bermanfaat dalam mendorong kemajuan petani Indonsia.

\section{Daftar Referensi}

Ahda, Fadhli Almu'iini. "Aplikasi Penentuan Jenis Penyakit Yang Memungkinkan Bisa Diterapi Dengan Bawang Merah Dengan Menggunakan Metode Naïve Bayes." Jurnal Ilmiah Teknologi Informasi Asia 9, no. 1 (2015): 34-44.

Aldila, Haris Fatori, Anna Fariyanti, and Netti Tinaprilla. "Daya Saing Bawang Merah Di Wilayah Sentra Produksi Di Indonesia." Jurnal Manajemen \& Agribisnis 14, no. 1 (2017): 43.

Fatchiya, Anna, and Siti Amanah. "Penerapan Inovasi Teknologi Pertanian Dan Hubungannya Dengan Ketahanan Pangan Rumah Tangga Petani.” Jurnal Penyuluhan 12, no. 2 (2016): 190-197.

Febriantoko, Jovan, and Hendra Rotama. "Evaluasi Potensi Penerimaan Pendapatan Asli Daerah Bidang Pariwisata Di Indonesia" (2018).

Gelling, L. "Qualitative Research," Qual. Res., 2015.

Olsen, Wendy. "Observation Methods." Data Collect. Key Debates Methods Soc. Res (2012).

Septiawati, Rani, Aci Murhad, Dina Dinata, Reni Anggainy, Winda Sari, and Febrianty Febrianty. "Pemanfaatan Limbah Kain Perca Sebagai Alternatif Peluang Usaha." Comvice: Journal of community service 3, no. 1 (2019): 1-8.

Waluyo, Dwi Eko, Uci Yuliati, and Joko Triwanto. "IbM Pondok Pesantren Wirausaha Agro Industri." IbM Pondok Pesantren Wirausaha Agro Industri 3, no. 1 (2016): 924. 